\title{
ANALYSIS OF STUDENTS' SELF-ESTEEM AND ACADEMIC PERFORMANCE OF PHYSICS STUDENTS IN SENIOR SECONDARY SCHOOLS IN PORT- HARCOURT LOCAL GOVERNMENT AREA
}

\author{
Omeodu M. D. \\ Department of Science Education, Rivers State University, Port-Harcourt \\ Corresponding Email: dididjond@yahoo.co.nz
}

Cite this article:

Omeodu M.D. (2021),

Analysis of Students' Self-

Esteem and Academic

Performance of Physics

Students in Senior Secondary

Schools in Port-Harcourt

Local Government Area.

British Journal of

Contemporary Education 1(1), 75-83. DOI: 10.52589/BJCEPJ2LCMEM.

\section{Manuscript History}

Received: 18 Aug 2021

Accepted: 13 Sept 2021

Published: 27 Sept 2021

Copyright $(\odot) 2020$ The Author(s). This is an Open Access article distributed under the terms of Creative Commons AttributionNonCommercial-NoDerivatives 4.0 International (CC BY-NC-ND

4.0 ), which permits anyone to share, use, reproduce and redistribute in any medium, provided the original author and source are credited.

\begin{abstract}
The study critically examined the influence selfesteem on students' academic performance in physics in senior secondary schools in Port-Harcourt Local Government Area. The purpose of the study was to examine the influence of self-esteem on the academic performance of students with respect to gender. Three research questions and one hypothesis were posed to guide the study to find out the relationship between students' selfesteem and their academic achievement. The instruments used for the study include a standardized questionnaire developed by Rosenberg (1965), titled "Rosenberg self esteem scale", and Physics Achievement Test (PAT) developed by the researcher. This test comprised 50 multiple choice questions which cover subjects from SSS1 to SSS3. The PAT was subjected to a validation process and the reliability coefficient obtained was 0.88 through Kuder-Richardson 21. The findings of the study showed that 68 percent of the respondents have low self-esteem while 32 percent are high self-esteemed students. The mean difference (10.04) showed that students with low self-esteem performed poorly compared to students with high self-esteem. The hypothesis revealed that there is a strong positive relationship between the two variables under study, that is students' self-esteem and their academic performance in physics. The study recommended that physics teachers should recognize the level of each of the students' self-esteem. Teachers should also allocate time to raise the level of students' self confidence before teaching difficult topics in Physics.
\end{abstract}

KEYWORDS: Influence, Self-Esteem, Academic Performance, Senior Secondary Schools. 


\section{INTRODUCTION}

Self-esteem is one of the influential factors that affect students' academic achievement which has received increasing attention. Sedikides and Gress (2003) described self-esteem as the perception of individuals or personal evaluation of self-worth, one's feelings of self-respect and self-confidence and the rate at which an individual has positive or negative views about his/herself. In the view of Murphy, Stosny and Morrel (2005), self-esteem could be referred to as an instrument for measuring self-worth, involving cognitive evaluation about general selfworth and affective experiences of the self that are linked to these global appraisals. Selfesteem is the cognitive and affective perception an individual has about oneself's worth.

Brown, Dutton, and Cook in Abdel-Khalek (2016) distinguished three ways in which the term "self-esteem" is used: (a) global or trait self-esteem to refer to the way people characteristically feel about themselves, i.e. feelings of affection for oneself; (b) selfevaluation to refer to the way people evaluate their various abilities and attributes, and (c) feelings of self-esteem to refer to momentary emotional states, e.g. a person might say her self-esteem was sky-high after getting a big promotion, or a person might say his self-esteem plummeted after a divorce.

This construct comes to play when children compare their self-evaluation with actual performance on a variety of tasks. Hence, this comparison between the perceived self and the ideal self is very crucial specifically during adolescence because adolescents are faced with a diversified job of developing and also challenges of their own age. Hence, development of selfesteem is considered one of the most important developmental processes of adolescence (Sirin \& Rogers-Sirin, 2004).

Rosenberg self-esteem scale is the most popular instrument used in determining the state of an individual's self-esteem. The scale posits that the higher the score of the respondent, the higher the self-esteem. High self-esteem score is a must factor in order to attain the feeling of happiness (Abdel-Khalek, 2016). Studies have identified self-esteem as an important determinant of emotional well-being (Baumeister, Campbell, Krueger \& Vohs, 2003). The study of Berger, Alcalay, Toretti and Milicic (2009) illustrated the relationship between students' emotional wellbeing and academic achievement. The results showed that emotional wellbeing correlated positively with academic achievement. Similarly, the experience of positive emotions is related to more creative thinking (Fredrickson, 2004). Positive emotions can promote the process of inventive and empathetic thinking (Seligman et al. in Bianca, 2017). High self-esteem helps individuals to view themselves as active and capable persons to promote changes through effort and set higher goals which culminate in learning new things. Interestingly, numerous researchers have demonstrated that the best way to improve students' achievement is to increase their self-esteem (Rubie et al., 2004). Research has also documented that high self-esteem plays an important role in academic achievement, social and personal responsibility (Redenbach, 1991). Those who have higher academic achievement tend to feel more confident; in contrast, those who lack confidence in themselves achieve less.

Gender is the important factor which influences the growth, emergence and demonstration of self-esteem. Numerous differences have been found between males and females in their level of self-esteem during adolescence because they tend to adopt gender stereotypes. Specifically, male self-esteem is thought to be more influenced by goals characterized by independence and autonomy, while self-esteem in females is more influenced by goals related to interdependence 
and sensitivity (Cross \& Slater, 1995). The difference in self-esteem can lead to differences in academic achievement between boys and girls. It has been revealed that girls do better in school, get higher grades and graduate from high school at a higher level than boys (Jacob, 2002). The study of Kara and Kahraman (2008) revealed that there is a correlation between gender and self-esteem. However, the present study revealed the important role of self-esteem in the academic achievement of physics students. In other words, the present study aimed to investigate the relationship between self-esteem and academic achievement as well as gain insight into the differences in self-esteem and academic achievement between boys and girls.

Sadaat, Ghasemzadeh and Soleimani (2012) conducted a research, which aimed to study selfesteem and its determined link to the academic achievement of university students. According to the results obtained from a study on 370 students, a significant difference is observed in selfesteem among male and female students. However, for family self-esteem, male students received higher scores than female students $(\mathrm{t}=-2 / 12, \mathrm{p}<0.05)$. The students of the faculties of basic sciences, psychology and educational sciences, and electro-computers showed significant differences in self-esteem. Academic self-esteem and family self-esteem, on the meaningful level of $\mathrm{p}<0.05$, had a direct and positive relationship with the academic achievement of students.

Mohammad (2010) investigated the relationship between self-esteem and academic achievement in pre-university students. The objectives of this study were achieved by using the Coppersmith questionnaire and the students' grade in their current and previous semesters. The random sampling was used for collecting the data and consequently, 50 males and 50 females were chosen randomly. The questionnaires were distributed amongst 100 students in Qaemshahr schools. The results demonstrated that there was a significant positive relationship between self-esteem and academic achievement. Moreover, there was a significant difference in academic achievement between boys and girls. However, no significant difference was found in self-esteem between males and females. The results suggest that high self-esteem is an important factor and strengthen the prediction of academic achievement in students.

Twinomugisha (2008) conducted a study using a correlation design. It was carried out among the students of the United States International University in East Africa. The hypothesis of this study stated that if self-esteem increases, then academic success will increase also. A total of 37 participants took part. The researcher took a sample of the senior students to examine whether their self-esteem had increased and if the increase had any relationship with their academic success. The researcher also sought to examine whether there was a difference between the levels of self-esteem development among females and males and what relationship it may have with academic achievement. The Rosenberg Self Esteem Scale was used to measure the students' self-esteem state between their freshman year and their senior year for any developments. The scale is a ten item Likert scale with items answered on a four point scale - from strongly agree to strongly disagree. The scale has high reliability, test-retest correlations range from $0.82-0.88$, and Cronbach's alpha for various populations are in the range of $0.77-0.88$. The results of this research show that there was a positive relationship $(\mathrm{r}=$ .048) between self-esteem and CGPA. The results confirmed that there was a negative relationship between self-esteem and gender $(\mathrm{r}=-.316)$ and a positive relationship between CGPA and gender $(r=.057)$; the males' self-esteem and CGPA increased while the females' self-esteem decreased but their grades remained constant. The study concluded that there was a positive relationship between self-esteem and academic achievement although the relationship was weak. However, despite the wealth of studies on self-esteem, none has been 
centred on achievement in physics education. The necessity of this study is that there has been consistent poor performance of students in physics in external examination over the years, which remains an issue of concern to researchers. The present study was therefore undertaken to investigate students' self-esteem and students' academic performance in electromagnetism in senior secondary schools in Port-Harcourt Local Government Area of Rivers State, Nigeria.

\section{Purpose of the study}

The purpose of the study was to investigate students' self-esteem and academic performance in physics in senior secondary schools in PHALGA. Specifically, the study sought to

1. Determine the difference in the physics scores of students with high and low self-esteem in senior secondary schools in PHALGA.

2. Determine the difference in the physics scores of male students with high and low selfesteem in senior secondary schools in PHALGA.

3. Determine the difference in the physics scores of female students with high and low self-esteem in senior secondary schools in PHALGA.

\section{Research Questions}

1. What is the difference in the physics scores of students with high and low self-esteem in senior secondary schools in PHALGA?

2. What is the difference in the physics scores of male students with high and low selfesteem in senior secondary schools in PHALGA?

3. What is the difference in the physics scores of female students with high and low selfesteem in senior secondary schools in PHALGA?

\section{Hypothesis}

1. There is no significant relationship between self-esteem and students' academic performance in senior secondary schools in PHALGA.

\section{METHODOLOGY}

The study was carried out in Port-Harcourt Local Government Area of Rivers State. PortHarcourt is one of the twenty-three local government areas of Rivers State. There are myriads of private and public secondary schools operating within the local government. The study adopted ex post facto design. This design was used because the population of the study was all senior secondary science students in Port-Harcourt Local Government Area of Rivers State. Sampling of the study was done using simple random sampling techniques. Five public secondary schools were randomly selected and a balloting technique was used to randomly select ten SSS3 science students in each of the five secondary schools. Thus, the total sample size was 50. Among the fifty samples, 32 were males while 18 were females. There were two instruments used for this study: 
i. Physics Achievement Test (PAT): This test comprises 50 multiple choice questions which cover subjects from SSS1 to SSS3. Each of the test questions carries two (2) marks. The instrument was subjected to test discrimination and difficulty index using students in the selected school but not part of the study. The values obtained were 0.65 and 0.71 respectively. The reliability of the instrument was determined using KuderRichardson 21 which yielded a reliability coefficient of 0.88 .

ii. Rosenberg Self-esteem Scale: This is a standardized questionnaire commonly used to measure self-esteem. A 10-item scale that measures global self-worth by measuring both positive and negative feelings about the self. The scale is believed to be unidimensional. All items are answered using a 4-point Likert scale format ranging from strongly agree to strongly disagree. It is a 10-item scale that measures global selfworth by measuring both positive and negative feelings about the self. The scale is believed to be unidimensional. All items are answered using a 4-point Likert scale format ranging from strongly agree to strongly disagree (Rosenberg, 1965).

The Physics Achievement Test (PAT) was subjected to a validation process. Two physics teachers were given the test of ascertaining whether the test is valid in content and suitable for the selected categories of students. Reliability was carried out using the test-retest method and the coefficient value obtained was 0.96 . This suggests that the instrument is reliable. Mean and standard deviation was used to analyze the test scores of students. For Rosenberg self-esteem scale, items 2, 5, 6, 8, 9 are reverse scored. Give "Strongly Disagree" 1 point, "Disagree" 2 points, "Agree" 3 points, and "Strongly Agree" 4 points. Sum scores for all ten items. Keep scores on a continuous scale. Higher scores indicate higher self-esteem. Linear regression was used to test the hypothesis at 0.05 level of significance.

\section{RESULT}

Research Question 1: What is the difference in the physics scores of students with high and low self-esteem in senior secondary schools in PHALGA?

Table 1: Mean difference in the physics scores of students with high and low self-esteem in senior secondary schools in PHALGA

\begin{tabular}{lllll}
\hline Groups & N & Mean & S.D & $\begin{array}{l}\text { Mean } \\
\text { Difference }\end{array}$ \\
\hline Low self-esteem & $34(68.0)$ & 51.46 & 16.17 & \\
High self-esteem & $16(32.0)$ & 61.50 & 17.72 & 10.04 \\
Total & $50(100.0)$ & & & \\
\hline
\end{tabular}

Field Survey, 2021

Table 1 shows the influence of self-esteem on the academic performance of physics students in senior secondary schools in PHALGA. The findings showed that 68 percent of the respondents have low self-esteem while 32 percent are high self-esteemed students. Findings also revealed that the mean score of students with low self-esteem was 51.46 while the mean 
score of students with high self-esteem was 61.50. The mean difference (10.04) showed that students with low self-esteem performed poorly compared to students with high self-esteem.

Research Question 2: What is the influence of self-esteem on the academic performance of male students in physics in senior secondary schools in PHALGA?

Table 2: Influence of self-esteem on the academic performance of male students in physics in senior secondary schools in PHALGA

\begin{tabular}{lllll}
\hline Groups & N & Mean & S.D & $\begin{array}{l}\text { Mean } \\
\text { Difference }\end{array}$ \\
\hline Low self-esteem & $22(69.0)$ & 41.33 & 10.43 & 33.27 \\
High self-esteem & $10(31.0)$ & 74.60 & 6.40 & \\
Total & $32(100.0)$ & & & \\
\hline
\end{tabular}

Field experiment 2021

Table 2 shows the influence of self-esteem on the academic performance of students in physics in senior secondary schools in PHALGA. The findings showed that 69 percent of the male physics students have low self-esteem while 31 percent are high self-esteemed students. Findings also revealed that the mean score of male students with low self-esteem was 41.33 while the mean score of students with high self-esteem was 74.60. The mean difference (33.27) showed that male students with high self-esteem performed more excellently than students with low self-esteem.

Research Question 3: What is the influence of self-esteem on the academic performance of female students in physics in senior secondary schools in PHALGA?

Table 2: Influence of self-esteem on the academic performance of female students in physics in senior secondary schools in PHALGA

\begin{tabular}{lllll}
\hline Groups & N & Mean & S.D & $\begin{array}{l}\text { Mean } \\
\text { Difference }\end{array}$ \\
\hline Low self-esteem & $12(66.67)$ & 42.5 & 13.36 & 23.17 \\
High self-esteem & $6(33.33)$ & 65.67 & 12.48 & \\
Total & $18(100.0)$ & & & \\
\hline
\end{tabular}

Field Experiment, 2021

Table 3 shows the influence of self-esteem on the academic performance of female students in physics in senior secondary schools in PHALGA. The findings showed that 66.67 percent of the female physics students have low self-esteem while 33.33 percent are high self-esteemed students. Findings also revealed that the mean score of female students with low self-esteem 
was 42.50 while the mean score of students with high self-esteem was 65.67 . The mean difference (23.17) revealed that self-esteem influenced students' academic performance in that female students with high self-esteem had higher scores in physics than those with low selfesteem.

\section{Hypothesis}

1. There is no significant relationship between self-esteem and students' academic performance in senior secondary schools in PHALGA.

Table 3: Pearson product moment correlation (PPMC) on the relationship between selfesteem and students' academic performance in senior secondary schools in PHALGA

\begin{tabular}{llrr}
\multicolumn{4}{c}{ Correlations } \\
\hline \multicolumn{1}{c}{ Self-esteem } & \multicolumn{1}{c}{ PAT } \\
\hline Self- & Pearson Correlation & 1 & $.814^{* *}$ \\
esteem & Sig. (2-tailed) & & .000 \\
& N & 50 & 50 \\
PAT & Pearson Correlation & $.814^{* *}$ & 1 \\
& Sig. (2-tailed) & .000 & \\
& N & 50 & 50 \\
\hline
\end{tabular}

**. Correlation is significant at the 0.01 level (2-tailed).

Table 4 presents the result of the hypothesis tested at 0.05 level of significance. The hypothesis was tested to show whether a relationship exists between students' self-esteem and students' performance in physics. If a relationship then exists, how significant is it statistically? The result showed that the $r$-value is 0.815 . This implies that there is a strong positive relationship between the two variables under study, that is students' self-esteem and their academic performance. The p-value of 0.000 was obtained which is within the range of the significant level of 0.05 ( $p<0.05)$. The implication of this is that the null hypothesis was rejected; that is, there is a significant relationship between self-esteem and students' academic performance in senior secondary schools in PHALGA.

\section{DISCUSSION OF FINDING}

Table 1 shows the influence of self-esteem on the academic performance of physics students in senior secondary schools in PHALGA. The findings showed that 68 percent of the respondents have low self-esteem while 32 percent are high self-esteemed students. Findings also revealed that the mean score of students with low self-esteem was 51.46 while the mean score of students with high self-esteem was 61.50. The mean difference (10.04) showed that students with low self-esteem performed poorly compared to students with high self esteem.

Table 2 shows the influence of self-esteem on the academic performance of students in physics in senior secondary schools in PHALGA. The findings showed that 69 percent of the male physics students have low self-esteem while 31 percent are high self-esteemed students. 
Findings also revealed that the mean score of male students with low self-esteem was 41.33 while the mean score of students with high self-esteem was 74.60. The mean difference (33.27) showed that male students with high self-esteem performed more excellently than students with low self-esteem.

Table 3 shows the influence of self-esteem on the academic performance of female students in physics in senior secondary schools in PHALGA. The findings showed that 66.67 percent of the female physics students have low self-esteem while 33.33 percent are high self-esteemed students. Findings also revealed that the mean score of female students with low self-esteem was 42.50 while the mean score of students with high self-esteem was 65.67 . The mean difference (23.17) revealed that self-esteem influenced students' academic performance in that female students with high self-esteem had higher scores in physics than those with low selfesteem.

\section{CONCLUSION}

The study concludes that self-esteem has a very strong relationship with students' performance in physics. The findings made the researcher conclude that gender influences self-esteem because high self-esteem was mostly recorded among the males while low self-esteem was common among the females. Those students who have high self-esteem perform well in physics compared to their counterparts. The researcher suggests perhaps students' level of intelligence has caused an improvement in their self-esteem. Whereas students' low level of intelligence may have been the reason for low self-esteem.

\section{RECOMMENDATIONS}

The study recommended that

1. Physics teachers should recognize the level of each of the students' self-esteem. Therefore, the teacher should allocate time to raise the level of students' self-confidence before teaching difficult topics in physics.

2. Physics teachers should ensure that they are careful in their use of words to students as this may cause a drop in students' level of self-esteem. Derogatory words may trigger low self-esteem among students.

\section{REFERENCES}

Abdel-Khalek, A. (2016) Introduction to the Psychology of self-esteem in Self-esteem: perspectives, influences, and improvement strategies. Nova Science publishers

Baumeister, R.F., Campbell, J.D., Krueger, J.I. \& Vohs, K.D. (2003). Does High Self-Esteem Cause Better Performance, Interpersonal Success, Happiness, or Healthier Lifestyles? Psychological Science in the Public Interest, 4(1), 1-44. 
Berger, C., Alcalay, L., Torretti, A., \& Milicic, N. (2011). Socio-emotional well-being and academic achievement: Evidence from a multilevel approach. Psicologia: Reflexão e Crítica, 24(2), 344-351

Bianca, F. (2017). The relationship between wellbeing and academic achievement A systematic review. Master's Thesis, University of Twente

Cross, T. \& Slater, R.B. (1995). A first view of the academic performance of African Americans at three highly ranked colleges. Journal of Blacks Higher Education, 7: 7679.

Fredrickson, B. L. (2004). The broaden-and-build theory of positive emotions. Philosophical Transactions-Royal Society of London Series B: Biological sciences 359 (1449), 13671378.

Jacob, B.A., (2002). Where the boys aren't: Non-cognitive skills, returns to school and the gender gap in higher education. Economics Education Review., 21: 589-598.

Kara, I. \& Kahraman, O. (2008). The effect of computer assisted instruction on the achievement of students on the instruction of physics topic of 7 th grade science course at a primary school. Journal of Applied Science, 8: 1067-1072.

Mohammad, A. (2010). Relationship Between Self-esteem and Academic Achievement Amongst Pre-University Students. Journal of Applied Sciences (12) 2010; DOI: 10.3923/jas.2010.2474.2477

Murphy, C. M., Stosny, S. \& Morrel, T. M. (2005). Change in self-esteem and physical aggression during treatment for partner violent men. Journal of Family Violence, 20, 201-210.

Redenbach, S., 1991. Self-Esteem, the Necessary Ingredient for Success. Esteem Seminar Programs and Publications, USA.

Rubie, C.M., M.A.R. Townsend \& Moore, D.M. (2004). Motivational and academic effects of cultural experiences for indigenous minority students in New Zealand. Educational. Psychology, 24: 143-160.

Sadaat, M., Ghasemzadeh, A. \& Soleimani, M. (2012). Self-esteem in Iranian university students and its relationship with academic achievement. Procedia - Social and Behavioural Sciences, 31, 2012, Pages 10-14. doi:10.1016/j.sbspro.2011.12.007

Sedikides, C. \& Gress, A. P. (2003). Portraits of the self. In M. A. Hogg and J. Cooper (Eds.), Sage handbook of social psychology (pp. 110-138). London: Sage.

Sirin, S.R. \& Rogers-Sirin, L. (2004). Exploring school engagement of middle-class African American adolescents. Journal of Youth Sociology., 35: 323-340.

Twinomugisha, S.R. (2008). The relationship between Seld-esteem and academic achievement. Retrieved from http://www.academia edu/ 836793 1/self_esteem_ and_academic_achievement. 